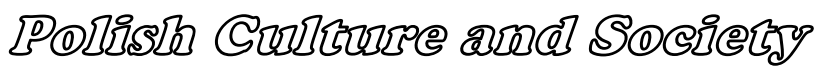

\section{Shaping the multicultural society of Lower Silesia after the Second World War exemplified by the case of Dobroszyce}

\author{
Marta Hold \\ Marta Hold@interia.pl
}

\begin{abstract}
World War II and its political consequences resulted in a demographic shift in Lower Silesia. It took place to an extent never before seen in any part of Europe. Due to international decisions concerning the changes of its borders, Lower Silesia was once again integrated with Poland. At the same time the German inhabitants living in the region were obliged to leave. Polish people replaced them coming from other parts of Poland as well as from former Polish territories which had been incorporated by the Soviet Union.

The immigrants were influenced by the cultures of the places of their origin. They differed in almost every field of everyday life, so in their new towns they met people with various integrating capabilities, contrasting points of view, political preferences and attitudes. That phenomenon was understood as a coexistence of the representatives of at least two different cultures whose members perceive the differences between them. Prevalence of so many distinct cultures in one area and the influences they had on each other led to the creation of specific cultural and social relations among the groups and their members. The situation obliged the settlers to overcome their particular attitudes and competences to live and communicate with new neighbours.

Significant historical processes had influenced in a noticeable way the lives of people from every single town and village in Lower Silesia. One example of the place chosen by the immigrants to Lower Silesia is Dobroszyce. The incoming people created from the very beginning a society which was supposed to live in multicultural reality.
\end{abstract}

Key words: multicultural society, multicultural relations, cultural diversity, demographic shift in Lower Silesia, deportations, immigrants, cultural and social relations. 
Lower Silesia (Dolny Ślask) is a region in the South-West of Poland which consists of the Lower Silesia province and parts of Lubuskie and Opolskie provinces. It has borders with the Czech Republic and Germany. The southern border of Lower Silesia is delineated by the mountain ridge of the Sudeten range, the western has been determined since 1945 by the Nysa Łużycka river, the northern by the Barycz river and from the south with the Wielkopolska region. The eastern border runs along the lower Nysa Kłodzka region and Stobrawa valley up to the Trzebnickie Hills and the spring of the Barycz river. Wrocław, situated on the Odra river in the Silesian Lowland (pol. Nizina Sląska) is the capital of Lower Silesia. This is one of the fastest developing regions of Poland which "may be characterized by its impressive scenery, tourism opportunities, economy, culture and scientific assets. The region is placed third in Poland according to gross domestic product (GDP) for each inhabitant. One of the strongest factors of Lower Silesia, apart from its situation at the great geographical crossing of important routes in Poland, is as a meeting point of many cultures and cultural diversity, identifiable in the mixed and different traditions and customs rooted in a rich history" (Chodorowska 2006, p. 7). According to A. Chodorowska "multiculturalism and multiplicity of ethnic groups create a situation in which almost every nation finds a reference point in the culture of the region" (Chodorowska 2006, p. 9). This is the consequence of the numerous and complicated historical processes which took place within these territories.

Lower Silesia has had many rulers throughout the centuries. "Since the 10th century [Lower Silesia] has been incorporated by various countries - the Monarchy of Piast in Poland, the Kingdom of the Czechs, the Austrian Habsburg Monarchy, Prussia and The German Reich. Finally, after World War II, Lower Silesia has been placed within Polish borders" (Berendt 2000a, p. 8). The biggest changes in the history of the region appeared after the end of the war and were the result of negotiations between the allies in 1945. "In the past the region was affected by changes in borders, countries, sovereigns or capitals to which the people paid taxes, but there always remained the same neighbourhoods, fixed street names and familiar language. In 1945 Lower Silesia not only changed owner once again, but it was also the first time in its history that border transformation was followed by a shift in the demography of the people living there" (Urbanek 2003, p. 11). It may be remarked that in the case of Lower Silesia the end of the World War II was at the same time the end of "cross-border existence of the region. It was the end of the continuity of multicultural development which had been typical for the area despite the wars, the changing borders and the diversity of the social groups diverse from ethnic, cultural and religious points of view. It was the first time that one country controlled the region with its material wealth and natural resources but without the people who used to live 
there and whose ancestors had lived there for centuries. By that process Lower Silesia transformed its profile from German to Polish, and as a result the national and ethnic groups which used to dominate, became marginal" (Kaszuba 2002, p. 463).

World War II and its political consequences resulted in a demographic shift in Lower Silesia. It took place to an extent never before seen in any part of Europe. Due to international decisions concerning the changes of the borders, Lower Silesia was once again integrated with Poland ${ }^{17}$. At the same time the German inhabitants living in the region were obliged to leave. Polish people replaced them coming from other parts of Poland as well as from former Polish territories which had been incorporated by the Soviet Union. That solution was approved by the peace treaties signed in Yalta, Teheran and Potsdam. "As a result of the decisions ending World War II made in Potsdam and signed by the heads of the victorious countries: Roosevelt, Churchill and Stalin, the transformation of Polish borders became a fact. The eastern border was shifted to the Bug river, in the west it was set up along the Odra and Nysa Łużycka rivers. Following this, Poland lost Kresy ${ }^{18}$ to the Soviet Union. The loss of the eastern lands was supposed to be replaced by the annexation of the terrains belonging to Germany before World War II. Thus was justified on historical reasons that centuries before the area had originally been Polish and hence it was called in Polish propaganda, "the Recovered Lands" (Berendt 2000b, p. 141).

These decisions led to enormous, planned deportation whose purpose was national unification within the borders of the countries. Moreover, it served as a solution to the problem of minority groups in the new political organization of Europe. Authorities in Poland in fact were part of the communist system supporting the idea of a nationally homogeneous country. "It was justified by the negative experience of Poland and by necessity of the appropriate relations with the neighbouring countries" (Ciesielski 1999, p. 13). As early as 9th September 1944 the Polish Committee of National Liberation (PKWN)19 and the States of National Councils of the Ukrainian and Belarusian SRR signed in Lublin two, almost identical, accords (Polish-Ukrainian and Polish-Belarusian) concerning the rules of deportation. A few days later, on 22nd September 1944, an analogical arrangement was made with the Lithuanian SRR. "The

\footnotetext{
${ }^{17}$ The last time when Lower Silesia was within the borders of Poland was in the 13th century when that region was lost in the battles with Germany and never came back to Poland till the 1945 on the strength of Yałta conference decisions.

${ }^{18}$ Term Kresy means outskirts or borderlines and concerns the Polish eastern frontier. During the period of the Second Polish Republic, these territories roughly equated with the lands to the east of Curzon Line.

${ }^{19}$ The Polish Committee of National Liberation was a provisional government of Poland, officially proclaimed on the $21^{\text {st }}$ of July 1944 under the direction of State National Council (KRN) in opposition to the Polish government in exile. It exercised control over Polish territory re-taken from Nazi Germany and was fully sponsored and controlled by the Union of Soviet Socialist Republics.
} 
three accords regulated the deportation from other countries to Poland as well as the other nationalities from Poland to certain Soviet Socialist Republics. The deportations were supposed to be entirely voluntary. (...) The deported people could take with them their clothes, shoes, underclothes, sheets, nutrition, the house equipment, everything up to a maximum weight 2 tons per family. Apart from thus they were allowed to take domestic cattle and fowl. Professionals could take the tools necessary for their occupations" (Ciesielski 1999, p. 14-15). It was forbidden to carry more than one thousand roubles of money in cash per person, and there was a prohibition on gold, platinum, gemstones, works of art, arms, soldiers' equipment, furniture, cars, motorcycles, photographs (apart from personal pictures), plans and maps.

Simultaneously during the last months of the war, the "evacuation" of Germans from the Recovered Territories began. It was obvious that after the war experience, the coexistence of Polish and German nations was not possible in one place. Moreover, there were already people arriving, being deported from Kresy and the immigrants from other parts of Poland. Hence, it was simply impossible to double the number of inhabitants in the region. For the Polish deportee who came to Lower Silesia the properties of the previous residents were supposed to be compensation for the loss of all their possessions and fortunes from where they used to live.

To ensure their rights for the Recovered Territories, the new Polish officials started the German expulsion from Lower Silesia from the very beginning of 1945. This action had been designed for the refugees coming from the East and was supposed to have set the example of applying the law within the Recovered Lands. Today it is called a "wild" expulsion. Nevertheless, the expulsion of Germans living in Lower Silesia was legitimised by the Allies during the Potsdam conference as well as within the accords signed in 1946 by the Allied government in Germany. In general there were about one million Germans transferred to the occupied zones of Germany" (Czapliński 2008, p. 12).

After World War II most of the migrating people settled in the Polish Recovered Territories to a large extent due to the ability of that region to absorb them. Nevertheless, the immigrants also encountered some difficulties, for example they couldn't access certain buildings which were still occupied by the Soviet Army. Then there was the remarkable lack of any administration system, no sense of security and the destruction of properties. After the national shift in the area of Lower Silesia, the region was settled by various ethnic groups which at the beginning did not create a coherent society. The new inhabitants lived together but as they came from different countries, they varied considerably regarding tradition, mentality, and experiences. "In the newly created societies with vivid memories of the war, regional customs took precedence over national ones. The immigrants were influenced by the 
cultures of the places of their origin. They differed in almost every field of everyday life, so in their new towns they met people with various integrating capabilities, contrasting points of view, political preferences and attitudes" (Kaszuba 2002, p. 450). Among the immigrants coming to post war Lower Silesia the following three essential groups may be distinguished:

1. Internal immigrants from central and southern Poland;

2. Repatriates and deported people from The Soviet Union (former Kresy);

3. Repatriates and re-emigrates from other countries.

The most numerous group consisted of the internal immigrants. They had priority for settlement in the region because of the fact that it was easier for them to move within country borders without crossing them. Moreover, they were not restrained by access to means of transport. Deportation was a voluntary choice which gave them hope for a better future with better living conditions. Finally, they had never felt that their movement meant a definitive cut from the place and society where they used to live. In their mind they always had the possibility to go back to where they came from or at least they were sure to have the ability to keep in touch with their families and friends. "The internal immigrants had created a comprehensive society with a diversity of attitudes, points of view, reasons for their arrival in Silesia (...) their nationality and social affiliation enabled them to claim that in that group people for whom material reasons were the most important were predominant. The priority of their migration, perspectives for social promotion and material enrichment resulted in the acceptance of the new living conditions that became easier and contributed to the positive image of the new government in charge of the transformation" (Kaszuba 2002, p. 450).

Those deported from Kresy constituted a significant group of immigrants into Lower Silesia. Nevertheless, for them it was a drastic change and one to which they had been forced by the political decisions and governmental accords. It was necessary for them to cut ties with the places where they grew up, leave their relatives and friends. All that was accompanied by feelings of compulsion and injustice. "Up to the end of 1947, 121846 were deported from Lithuania, 247936 from Belarus and 612405 from Ukraine and moved into the Recovered Territories" (Ciesielski 1999, p. 45). It was a proportional system of deportation based on the so called "parallels rule" which referred to the condition that people upon moving were changing their places of living according to the parallels, so that after migration they found conditions comparable to those which they had left. In other words, they retained a more or less similar geographical atmosphere. "The deported came from seven provinces of the former Kresy. The dominant province was Lviv, then Wilno, Tarnopol, Wołyń, Stanisławów, Polesie and Novogród provinces. The people from Kresy didn't have many possibilities to choose a place to stay. That evoked a 
conviction of limits existing in a new area and resulted in disturbed acclimatization, all due to the feeling of compulsion. In consequence, adjustment to the new environment became much more difficult, resulted in homesickness and enforced the opposition to a communist government which was blamed for the loss of the little homelands. Those deported from Kresy did not share the hope of the internal immigrants that one day they would be able to return to their homes. Because of their hope to go back to their motherlands they created a social group prone to a psychosis of temporariness and the feeling that another Polish border shift might be possible. That feeling was typical for those who moved to the former German territories where nobody was sure if and how long the new borders would be kept in their current state" (Kaszuba 2002, p. 450).

The decision about coming to the Lower Silesia was the immigrants own choice as far as other countries like Romania, Yugoslavia, France or Belgium were concerned, as they - after the centuries - were coming to the land of their ancestors. There was also another group of new Lower Silesia incomers, called "the army settlers" who came there to prepare the region for the arriving soldiers and their families and in the end they also settled in the recovered territories. Apart from the settlement and deporting ${ }^{20}$ action, as the result of political asylum to Lower Silesia, Greek and Macedonian immigrants arrived, forced to leave their motherlands after the fall of the communist uprising. "According to the statistical data from 1950, 1698911 people lived on the Recovered Territories including: 906998 internal immigrants from southern and central Poland, 593348 from the lands annexed to the Soviet Union and 69800 from Romania and Yugoslavia.

Table 1. The main orientations of the settlement directions in Lower Silesia

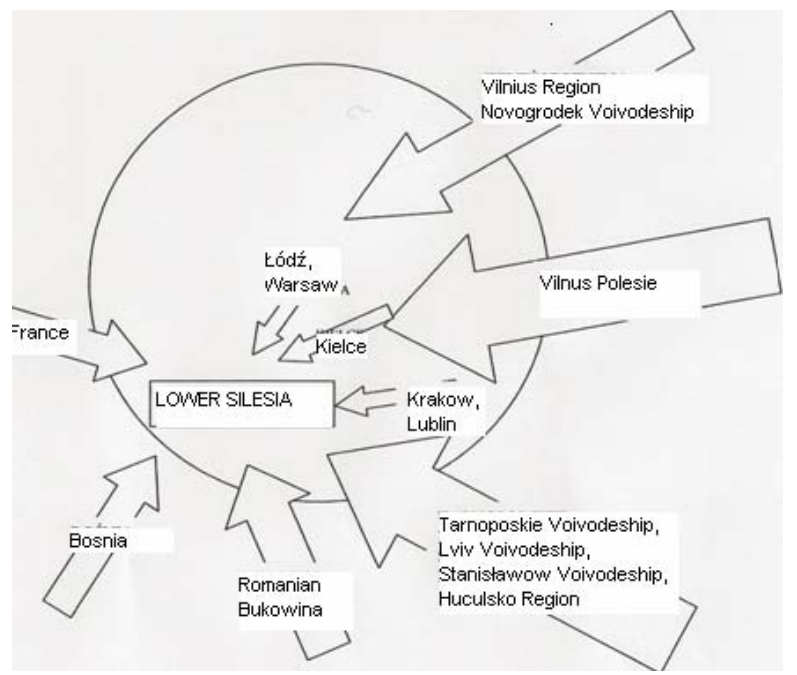

Prepared by Author

\footnotetext{
${ }^{20}$ Akcja osadniczo-przesiedleńcza means in direct translation the action of deporting people from one place and settling them in another region, in that case in Lower Silesia.
} 
New settlers comprised communities of various people who used to live in the thousands of towns and villages destroyed after the war. An example of a place chosen by the immigrants to Lower Silesia is Dobroszyce. The incoming people had created from the very beginning a society which was supposed to live in multicultural reality. The deported met in a new place of living "buildings partially with equipment, some tools of work, documents concerning the history of the place and its previous inhabitants indicating the area as the meeting point of various ethnic groups. In Lower Silesia history had to continue with those who came there because of different reasons" (Berendt 2000b, p. 142). The new settlers created the culture of Lower Silesia which gave a base for today's society. The new reality for dwellers was confronting many diversities, various beliefs, expectations and attitudes accepted by the new group or not.

In the society shaped after World War II the multicultural relations among the new inhabitants of Lower Silesia were noticed. That phenomenon was understood as a coexistence of the representatives of at least two different cultures whose members perceive the differences between them. Prevalence of so many distinct cultures in one area and the influence each had on the others led to the creation of specific cultural and social relations among the groups and their members. The situation obliged the settlers to overcome their particular attitudes and competences to live and communicate with new neighbours. It is explained by Szerlag who claims: "These are individuals who create the social relations in the area where are present two or more culture groups. Among them there may be distinguished some small communities: ethnographic, linguistic, religious or national. Furthermore, living in that kind of society obliged people to get used to the situation of "diversity" (Szerlag 2001, p. 26).

The scientists who explore the idea of multicultural societies (e.g. M. Albiński, J. M. G. Thurlings, L. V. Thomas) distinguish different levels of intercultural relations. One of these is the idea of M. Albański who indicates the following types of multicultural society organization: "escape", "territorial segregation", "underground living”, "isolationism", "practical openness", "ideological openness" and "assimilation". L.V. Thomas points to "passive opposition (isolation), "active opposition" (which is characterized by insisting on the purity of one`s own culture), so called "slackness assimilation", "peaceful assimilation", "accommodation" (when coexistence is connected with indifference) and finally “cooperation" when the groups are complementary (Compare: Golka 1997, p. 55). M. Golka in a simplified pattern presents all possible intercultural relations:

1. Open antagonism

2. Passive antagonism 
3. Segregation or isolation, public and hidden

4. Sham coexistence which is based on mutual accommodation

5. Assimilation connected with complete, mutual acceptance and cooperation (Golka 1997, p. 55).

Therefore "the relations existing in the multicultural society, might be presented as a continuum starting from those antagonistic ones which disable either communication or understanding entirely, and ending with the full coordination and coexistence of one group in confrontation with some dominating culture, with mutual sanctioning of practices facilitating acceptance" (Szerląg 2001, p. 29).

From the very beginning there were many problems with the multiculturalism of the society created in Lower Silesia. "The society composed of people so different from every point of view still exists. To achieve this goal those who created it had to face many cultural disharmonies coming from various traditional backgrounds, nutrition customs or methods of work. (...) Regional differences as well as the ethnic ones were remarkable in every field of social life, particularly in the traditions concerning clothes and language which kept their original character" (Berendt 2000b, p. 147). It took many years for so diverse a society to integrate and to feel attached to Lower Silesia as their own land. Moreover, the assimilation was disturbed by the policy of the communist state whose government provided anti-German propaganda.

Shortly after the war "Lower Silesia was filled with an atmosphere of prejudice. People lived with never-ending quarrels among the different social groups which tried to alienate one from another, but on the other hand were forced to stay together in one area. It was a method for those who didn't come from Poland to deal with the feeling of homesickness and with the alienation in a new place. On the other hand, the behaviour of the autochthons was concentrated on the protection of their territory from intruders. (...) An integral feature of people living in Lower Silesia, even more important than their nationality, turned out to be regional diversity. Intolerance for any kind of difference which concerned not only the national or language purity became a feature unusually common in the recovered territories. The antagonistic reactions and contempt were caused by the differences noticeable in the culture, customs, regional languages, clothes, work traditions, etc." (Kaszuba 2002, p. 463). There were some nick-names used by the new settlers in Lower Silesia which proved the aversion among them. Hence, the autochthons were called "Szwab", "Luterak" or 
"Niemiec"21. The immigrants from the east were called "Rusacy", "Parsiuki", and "Zabugole" 22 . Those who came from central Poland because of their poverty were called "centralacy", "bosi Antkowie" or "złodzieje",23. Finally, the immigrants from Ukraine were called "Ukraińcy", "chchałowie" and "kacapowie"24.

Significant historical processes had influenced in a noticeable way the lives of people from every single town and village in Lower Silesia. The transformation concerned also Dobroszyce, a village which until the 1945 belonged to Germany and existed under the name Juliusburg. Today it's a small town with about 6000 inhabitants constituting part of Oleśnica county, located in the northern part of the Oleśnica plain, on the cross roads of the route from Wrocław to Twardogóra and from Oleśnica to Trzebnica. Still, in $194540 \%$ of the inhabitants in Dobroszyce were Germans deported a short time after the border shift. By the end of 1946 they had almost disappeared from the region. That fact is mentioned by the first Vogt (wójt) of the village, Mr. Burzyński: "It was followed by the repatriation of Germans; we deported them from Dobroszyce and the villages nearby. We brought them to Oleśnica to a castle where we received an official confirmation that 1084 Germans had been moved away" (Burzyński, p. 3).

Dobroszyce as well as its closest neighbouring town Oleśnica had fortunately avoided the battles during the war and were liberated on the $21^{\text {st }}$ January 1945 . Hence, the Polish soldiers returning from the war or being deported from other territories had chosen Dobroszyce as it had not been destroyed as had other parts of Poland. The earliest immigrants were those who were returning after compulsory work in Nazi Germany and were stopped at the soviet check-point in Oleśnica. Then there were people coming from Kielce, Krakow, Poznań voivodeship and other regions of Poland, mostly from the Kresy. About $50 \%$ of the inflowing people came from two towns near Lviv: Sądowa Wisznia and Siemianówka. There was a special reason for deporting almost entire villages from one place to another: it was to keep the regional identity of their inhabitants due to the rule that "macro cosmos, preserved in a community, provides the opportunity to continue good relations among neighbours, enables

\footnotetext{
${ }^{21}$ Szwab in an every-day language means German. It's a term which comes from the name of Schwaben or Schwabenland, a historic region of Germany. Luterak this is, pronounced in Polish way, a pejorative name for Lutheranisme. Niemcy - the Germans, what at that time was a name with a pejorative meaning.

${ }^{22}$ Everything with a pejorative meaning, in the same order: Prusacy means with a negative signification - the Russian; the parsiuki; fianly the Zabugole described those who came from the region on the east of Bug river.

${ }^{23}$ Central Poland was a very poor region after the war so their nicknames were created according to that characteristic. So that "centralacy" concerned people from the center of Poland, bosi Antkowie, in a direct translation meant: Anthony's without shoes (Antek it's a name popular in the countryside were the people were very poor), and the third one - złodzieje means simply thieves.

${ }^{24}$ In a pejorative meaning the Ukrainians means the people from Ukraine, the chchałowie, the kacapowie.
} 
retaining of local authorities, but on the other hand sustaining the old disputes, customs and moral norms" (Berendt 2000b, p. 152). It also favoured the old prejudices as well, as is reflected in the words of a woman deported from Siemianówka to Dobroszyce, Maria Bajorek: "People in our village used to live in a Lviv atmosphere (Siemianówka was located 6 $\mathrm{km}$ from Lviv). Our plans for the future concerned only this town. The women from Siemianówka used to go there every day to sell milk. Our entire life was centred around this magic city. Those who lived in Wisznia Sądowa were more linked to Ukraine. Unlike them, we were placed in the centre of Polish atmosphere existing in Lviv. We thought Ukrainians were stubborn, quarrelsome, vengeful, jealous and mendacious people. So when we had to live with them in one village, it created many difficulties for us" (Oral account of Bajorek M., taken by Stępień in 1998). Actually it is still possible in Dobroszyce to hear, when somebody wants to offend another the use of the name "the Ukrainian from the Sacowa Wisznia" with a negative meaning.

The social adaptation from the very beginning concerned the closest environment and was based on the reconstruction of the previous reality of where the deported used to live. Those who came from Siemianówka usually chose the part of Dobroszyce by the small river Dobra with the old castle and the church. That location reminded them of their previous village located near Stawczanka, their "small motherland" with a court and a church on the hill. Among the oldest inhabitants of Dobroszyce the name 'Siemianówka' is still in use for that part of the village.

Apart from those deported from Lviv there were also immigrants from Kielce, Rzeszów and Kraków voivodeships as well as people from the Vilnius region. In that way Dobroszyce became the place where different cultures and mentalities met. The antagonisms were evident in every domain of life, in the quarrels, in the nicknames with pejorative meanings even in the interdiction of marriages with 'not ours' that meant those who didn't come from the same town. Usually people from the same town created strong groups closed to strangers. Hence, in the most difficult situation were those who were cut off from their natal villages and were forced to stay in an unknown place among unfriendly people. The difficulties appeared even in the obligations of everyday life like doing shopping in the market. M. Preniarz, deported from Vilnius region provides an example of the kind of discrimination: "It wasn't about hostility but when the shop assistant in a store was repatriated from one of the major groups, the women in the queue asked her not to sell too much to me because there wouldn't be enough left for 'their people'. They didn't even try to hide their resentments" (Oral account of Preniarz P., taken by Stępień in 1998). 
Antagonisms among the immigrants from Poland and those deported from the Kresy were most noticeable there. Even two years after the border transformation marriages between the representatives of the two groups were surprisingly rare. M. Bajorek from Rzeszów voivodeship recalls the early days of the relationship with his future wife deported from Siemianówka: "At the beginning we kept our love hidden that's why we used to meet after the church services or we would simply leave them to have some time just to ourselves. Otherwise it was not possible to meet because she came from Siemianówka and I was from Gorlice..." (Oral account taken on the $28^{\text {th }}$ of October 2008). Furthermore, there were parish registers which confirmed the difficulties of coexistence of the various social and national groups in Dobroszyce. In the register of marriages during the first two years after the war, marriages between the repatriates from Poland dominated. For them deportation was the beginning of new life with a chance for better future. Those deported from Kresy thought differently, with marriages coming in much later and not so frequently, according to the documents. For them Dobroszyce was just a temporary place to stay because they still kept the hope of returning to their motherlands. 'Mixed' marriages between those from Kresy and their new neighbours from Poland were rather rare.

The deported were aware of the importance of decisions taken at that time and about the significance of the occurring changes which were fundamental, personally for them as well as for following generations. Therefore they required the acceptance of the community and tried to aspire to the highest, traditional values. Usually people settled in Dobroszyce were deeply religious therefore to have a priest and a church in the town was essential to them. It should be emphasized that "the catholic church participated actively in the process of unification of the recovered territories. In this particular case the Church decided to exceed its normal obligations to support the process of integration of people coming from different social and ethnic groups" (Kaszuba 2002, p. 440). Similarly in Dobroszyce a leading role in the integration was played by the first provost of the local parish, priest Kasprzycki. Thanks to his activity, after the evacuation of the soviet army on $23^{\text {rd }}$ December 1945 , the church was saved and rebuilt later by all the inhabitants of Dobroszyce. The priest Kasprzycki recalls the events of that time: "We started the necessary renovation; we repaired the roof, put windows in the walls and prepared the interior to make it possible for the building to be used. Thanks to the hard work of the people the church was ready to use in a very short time" (Oral account of a priest Kasprzycki T., taken by a priest Kiełbasa A. in the 1970).

Marriages and baptisms became important events for the newly created community. M. Burzyński recalls: "The first marriage in Dobroszyce was entered into by M. Kubica and 
Ms. Kowala in the church in Wojska Polskiego street. It was such a joy for the whole village! We had been organizing a rehearsal every evening to prepare the surprise. As a result, we sang for them Veni Creator ${ }^{25}$ even without an organist which we simply didn't have at that time" (Burzyński, p. 2). Moreover, the church ceremonies created occasions to get to know each other. For instance, those who came from Siemianówka were characterized by the fact that they knew the entire text of the funeral mass by heart. The priest Kasprzycki mentioned: "When at the end of 1945 the priest started to sing Veni Creator during the marriage ceremony the repatriates from Siemianówka joined him immediately and sang loudly. What's more, they knew the funeral ceremony by heart" (Oral account of priest Kasprzycki T., taken by priest Kiełbasa A. in the 1970). Shortly after deportation for those who came to Dobroszyce being present at services was the best way to get familiar with their new neighbours. Christmas and Easter were particular ceremonies for which every group brought from their motherlands typical traditions. Even today there are some differences visible, for example, there are families which eat kutia and others where the traditional dish is makietki ${ }^{26}$.

Coexistence in the same village forced the newcomers to cooperate in the fields and farm work. In this case pragmatism defeated even the most striking social and historical barriers. "Among the Polish immigrants the process of integration and identification with the new locality proceeded rather quickly. They left behind the problems connected with the removal to a new place. In such a way the inhabitants of Dobroszyce started to organize administration, education or changes from the old German street names to new Polish ones. Works were the "local common goal" to everyone. Burzyński once more recalls the beginning of a Dobroszyce community: "When we were no longer under the control of the soviet army we started to live a normal life. (...) First of all we changed the street names from German to the Polish, Dobroszyce as a German town had been called Juliusburg but we changed it to Julianów. After that, priest Kasprzycki brought with him a map which concerned a period before partition of Poland, where our village was called Dobroszyce and that's why we changed it according to the traditional name. There were some inconveniences concerning the train station which was officially called Dobroszce. It was a question of one letter but it created a problem. To resolve it we had to write a request to the authorities (Burzyński, p. 1).

\footnotetext{
${ }^{25}$ Traditional Polish religious song.

${ }^{26}$ Kutia is a small square pasta with wheat, poppy seeds, nuts, raisins and honey, typically served during Christmas dinner whereas makietki is a Christmas Eve dessert and its main ingredients are: gingerbread extract, nuts and dried fruit, stewed strawberry and almonds.
} 
As the town name was established the inhabitants started to create a gmina ${ }^{27}$ essential for the administration of the area. The key posts for the village had to be taken by the new settlers who were in charge of establishing new structures. Burzyński writes in his diary: "There was no problem either with the hairdresser or with the carpenter, because Hajder took the barbershop and Szczepaniak took care of the carpenter`s workshop. It was more difficult to organize the life in the houses taken over after the Germans had left Dobroszyce. Upon departure they took with them or threw away most of their belongings so we had to organize everything for ourselves, even the furniture. (...)We used to exchange almost everything with the Russians for vodka, for example in that way we obtained three typewriters and even a clock. (...) The first transport of the repatriates arrived from Sądowa Wisznia. Among them was Ms. Sekunda who as a qualified nurse was our first doctor. She looked for aspirin in an old burnt out pharmacy and after that she treated us with what she had found. But we were so glad that she came with a white uniform" (Burzyński, p. 3-4). The stores, offices and other public institutions were established: "We set up a bakery with the first baker Pitio. The first artisans were Dykiert and Konopacki. As for the grocery stores the first were organized by Michalak and Borzek, Ms. Lodzina was responsible for the post office where the first postmen were Lachowicz and Rzeziński. M Załustowicz became the owner of Jutrzenka, the first restaurant in the village" (Burzyński, p. 5-6).

The new inhabitants did their best to organize their new homes. They renovated the buildings taken over after Germans left, organizing the farms and the public offices. There were activities which sometimes required buying many tools and equipment but even that did not discourage the new settlers. They found out easily that 'gorzelniana' ${ }^{28}$ was the best means of payment in Dobroszyce. It functioned in the transactions with the Soviets as well as with the local people. It was possible to buy almost everything from the Russians using vodka, even cows..." (Burzyński, p. 5) - reminds Burzyński.

A school was opened in Dobroszyce in 1946 and that was the official inauguration of the process of providing the education in the region. Its spiritual father was the first headmaster in a local school, M. Jaszczuk. Thanks to his efficiency a building was obtained near the old castle in order to establish a school. Then he found one more building in Wrocławska street which was also used for the needs of the students. He founded a school for the children from Dobroszyce and the area even for those who came from German families.

\footnotetext{
${ }^{27}$ Gmina is the municipal unit (lowest uniform level) of territorial division in Poland. It is usually translated as "commune" or "municipality".

${ }^{28}$ The kind of homemade vodka.
} 
All students were learning and studying together regardless of their nationality so that friendships among Polish and German children were natural in contrast to the enormous gap among their parents.

The goal of new settlers in Dobroszyce was to lead a normal life in a new place. In the name of that purpose "everybody worked as volunteers and it wasn't just about making it $100 \%$ effective. Everybody tried to create sufficient conditions for their families and their children to live in. It was still their motherland which had been simply removed from its previous location" (Stępień, p. 28). Thanks to the efforts of all inhabitants the town which had been strange at the beginning, became a real motherland afterwards. (...)With time, pragmatism overcame the social and historical divisions among the different groups who came to Dobroszyce. Finally marriages between the settlers from the different regions became usual" (Berendt 2000a, p. 150-153).

The generations following those who came to Lower Silesia in 1945 have created their identity based on the multicultural and multi-ethnic foundation of the region. It seems that it has been possible to adapt for so many different social groups in one village and the confirmation for that lies in the fact that most of the family names mentioned in the diaries of the progenitors exist in Dobroszyce up to the present day.

Translation: Katarzyna Olszewska Correction: mgr Justyna Pilarska

\section{Bibliography:}

Berendt E. (2000a), Wstęp, [in:] Kłodnicki Z. (ed.), Ślask, Schlesien, Slesko; Przenikanie kultur, Muzeum Narodowe we Wrocławiu, Wrocław.

Berendt E. (2000b), Powojenny kształt dolnoślaskiej tradycji ludowej, [in:] Kłodnicki Z. (ed.), Ślask, Schlesien, Slesko; Przenikanie kultur, Muzeum Narodowe we Wrocławiu, Wrocław.

Brzezińska A. I. (2006), Dzieciństwo $i$ dorastanie: Korzenie tożsamości osobowej $i$ społecznej, [in:] Brzezińska A.W., Hulewska A., Słomska J. (eds.), Edukacja regionalna, PWN, Warszawa.

Brzezińska A.W., Hulewska A., Słomska J. (2006) (eds.), Edukacja regionalna, PWN, Warszawa.

Burzyński L., Memorials, (text never published). 
Chodorowska A. (2006), Przywracanie kulturze dolnoślaskiej jej regionalnej specyfiki, ATUT, Wrocław.

Ciesielski S. (1999), Przesiedlenie ludności polskiej z Kresów Wschodnich do Polski 19441947, Neriton, Warszawa.

Czapliński M. (ed.) (2002), Historia Ślaska, Wydawnictwo Uniwersytetu Wrocławskiego, Wrocław.

Czapliński M. (2008), Komentarz historyczny, [in:] Tyszkowska K. (ed.), Skad my tu? Wspomnienia repatriantów, Wydawnictwo MAK, Wrocław.

Golka M (1997), Oblicza wielokulturowości, [in:] Kempny M., Kapciak A., Łodzinski S. (eds.), U progu wielokulturowości, Nowe oblicza społeczeństwa polskiego, Oficyna Naukowa, Warszawa.

Kaszuba E. (2002), Odbudowa i utrwalenie władzy (1945- 1948), [in:] Czapliński M. (ed.), Historia Ślaska, Wydawnictwo Uniwersytetu Wrocławskiego, Wrocław.

Kempny M., Kapciak A., Łodzinski S. (1997) (eds.), U progu wielokulturowości, Nowe oblicza społeczeństwa polskiego, Oficyna Naukowa, Warszawa.

Kłodnicki Z. (ed.) (1996), Dziedzictwo kulturowe Dolnego Ślaska, Polskie Towarzystwo Ludoznawcze, Wrocław.

Kłodnicki Z. (ed.) (2000), Ślask, Schlesien, Slesko; Przenikanie kultur, Muzeum Narodowe we Wrocławiu, Wrocław.

Rostworowska M. (1996), Nowi osadnicy, [in:] Kłodnicki Z. (ed.), Dziedzictwo kulturowe Dolnego Ślaska, Polskie Towarzystwo Ludoznawcze, Wrocław.

Stępień B., Ich nowa mała ojczyzna, (text of B. Stepień, never published).

Szerląg A. (2001), Ku wielokulturowości. Aksjologiczny sens wychowania w rodzinie na litewskim pograniczu kulturowym, „Impuls”, Kraków.

Tyszkowska K., (ed.) (2008), Ską my tu? Wspomnienia repatriantów, Atut, Wrocław.

Urbanek M. (2003), Dolny Ślask, Siedem stron świata, Wydawnictwo MAK, Wrocław. 